\title{
Review on Digital Transformation Policy of Directorate Generale of Taxes
}

\author{
Riyanto $^{1}$, Amalia Dewi Clarashinta ${ }^{2}$ \\ ${ }^{12}$ Directorate General of Taxes, Jakarta \\ Correspondent: riyanto.san@gmail.com ${ }^{1}$, bundachacho@gmail.com ${ }^{2}$
}

\author{
Received : August 08, 2021 \\ Accepted : August 25, 2021 \\ Published : October 31, 2021
}

\begin{abstract}
The Covid-19 pandemic caused reduction in face-to-face interaction between people. Changes in a social interaction from offline to online needs supporting facilities, both internet networks, computers, gadgets, and another item. The Directorate General of Taxes (DGT) as the government agency that collects state revenues from taxes, is constantly transforming towards improving public services especially to taxpayers. Many applications e-tax system that have been developed by DGT are Nadine, efaktur, e-billing, e-filling, and DJP Online. These an electronic reporting has influence on increasing of Annual Tax Return reporting for last three year.
\end{abstract}

Keywords: Public Service, E-Tax System, Annual Tax Return
Citation: Riyanto., Clarashinta, A.D. (2021). Review on Digital Transformation Policy of Directorate Generale of Taxes. Ilomata International Journal of Social Science, 2(4), 212-221. https://doi.org/10.52728/ijss.v2i4.353

(c) This is an open access article under the
CC-BY 4.0 license.

\section{INTRODUCTION}

The Covid-19 pandemic began in Wuhan, China at the end of 2019, spread throughout the whole world massively. The Indonesian President Joko Widodo on March 2, 2020, announced that two Depok residents were confirmed positive for Covid-19 (Susanti \& Widajatun, 2021; Tosepu et al., 2020). The increasing of people were infected of the COVID-19, has caused the government to take a policy of reducing activities between residents. The policy that have been carried out is the ' $5 \mathrm{M}$ ', namely using masks, washing hands, maintaining distance, staying away from crowds, and limiting mobility (Guo \& Shi, 2021; Windarwati et al., 2020).

The '5M' resulted in learning activities that were originally face-to-face to online, then buying and selling transactions were prioritized through applications, other activities also being online. Utilization of digital technology is important to support this process. The condition is a momentum to carry out digital transformation in all aspects, especially for company in order to serve consumers, as well as for government to service public (Cahyadini et al., 2021; $\underline{\text { Sreeramula }}$ \& Rahardjo, 2021).

The implementation of digital transformation by Ministry of Finance is carried out in the context of realizing good governance, as well as efforts to adapt the conditions of digital era that develop continuesly. In the 2021's Tax Day, Sri Mulyani as Minister of Finance, explained that tax reform must be able to take advantage in digital technology optimally. The Directorate General of Taxes as part of the Ministry of Finance, has made improvements both in terms of internal administration and service quality through digital transformation, especially during the Covid-19 pandemic (Hajawiyah et al., 2021; Tibulca, 2021). 
This article focus on the digital transformation of the Directorate General of Taxes to support internal administration, as well as to improve tax services both normal conditions, and during the Covid-19 pandemic. Physical direct service between tax officers and tax payers are things to be reduced, whereas tax services are important in the context of collecting tax.

\section{METHOD}

This research is a type of literature study research, with descriptive analysis used. Literature review is a critical analysis of the research conducted on a particular topic or question in the field of science. The literature study contains reviews, summaries, and an author's thoughts on several literature sources on the topics discussed. (Prastiwi \& Frecilia, 2014)

The literature study aims to analyze DGT's digital transformation policy and its implementation in order to provide excellent service to taxpayers. Data collection techniques are carried out by reviewing related regulations and their application in DGT's information and communication technology.

\section{RESULT AND DISCUSSION}

Digital transformation in a public service is needs to be implemented immediately in the digital era. Digital transformation as a way to rebuild business models following customer needs by using new technologies (Mergel et al., 2019). The adoption of digital technology aims to increase productivity, value creation, and social welfare (Ebert \& Duarte, 2018). Digital transformation, adopted from private sector, is mostly related to using new technologies to stay competitive in the Internet era, where services and products are delivered both online and offline. Transformation of online services is to increase adaptability and to automation through standardization (Amir et al., 2013; Mergel et al., 2019).

Digital transformation is a process by utilizing technology, human resources, and business processes that cause business performance changing. Digital transformation can be summed up as a comprehensive process that involves all resources including internet-based digital technology, to create an added value for the organization (

For reforming the bureaucracy of the Ministry of Finance, digital transformation is an important stage that must be carried out. Utilization of Information and Communication Technology (ICT) by the Directorate General of Taxes (DGT) as part of the Ministry of Finance, continues to be developed in order to support service activities to stakeholders both the government and the private sector as taxpayers (Rahwani et al., 2019).

Here are some of the rules which published by DGT towards modern digital transformation.

Table 1. Rules of Digital Transformation 


\begin{tabular}{ll}
\hline \multicolumn{1}{c}{ Number } & \multicolumn{1}{c}{ Tittle } \\
\hline PER-37/PJ/2010 & $\begin{array}{l}\text { Information and Communication Technology Governance Policy } \\
\text { of the Directorate General of Taxes }\end{array}$ \\
\hline PER-54/PJ/2010 & $\begin{array}{l}\text { Information and Communication Technology Development } \\
\text { Policy }\end{array}$ \\
\hline PER-51/PJ/2011 & Amendments to the Attachment of PER-54/PJ/2010 \\
\hline PER-46/PJ/2015 & $\begin{array}{l}\text { Blueprint for Information and Communication Technology of the } \\
\text { Directorate General of Taxes 2015 - 2019 }\end{array}$ \\
\hline PER-02/PJ/2016 & Second Amendment of PER-54/PJ/2010 \\
\hline PER-09/PJ/2017 & Third Amendment of PER-54/PJ/2010 \\
\hline
\end{tabular}

The pillars of Information and Communication Technology (ICT) developed by the Directorate General of Taxes (DGT) in the 2015-2019 ICT Blueprint, are Social Business, Mobile, Cloud Computing, and Big Data Analytics.

The Social Business Pillar directs the development of ICT-DGT to help explore people's behavior and living habits comprehensively. Social Business Pillar emphasizes that data and information needed by DGT is not only from formal sources, but also includes various informal sources of information that can be relied upon to explore tax base.

The Mobility Pillar directs development of ICT-DGT to have a widely reached, especially to people using mobile devices in their activities. Development of ICT oriented to mobile-first services, applications or information systems that were originally designed to be accessed via mobile devices, both by taxpayers and internal users of DGT. The Mobility Pillar was born to support excellent services to taxpayers anytime and anywhere.

The Cloud Computing Pillar directs the development of ICT-DGT to be flexible in the management of ICT infrastructure, by handing over the responsibility for managing the ICT infrastructure to cloud computing service providers. These pillars direct development of ICTDGT to be agile, it means the development of ICT-DGT is easy to adapt the changes.

Analytics is an integral process of DGT, especially in exploring tax base and preventing tax evasion. The Big Data Analytics pillar aims to strengthen analytics process that has been carried out at DGT by providing and utilizing big data, both structured data such as databases, and unstructured data such as data from various social media.

Several applications that have been developed by the Information and Communication Technology manager of the Directorate General of Taxes are Nadine, e-faktur, e-billing, e-filling, and DJP Online (Adi, 2020)

\section{Nadine as A New Mail Administration}

Electronic Service Manuscript (Naskah Dinas Elektronik / Nadine) is information recorded in electronic media as an official communication tool, which is made and or received by authorized officials within the Ministry of Finance.

Some of benefits by using Nadine are first, embodiment of the acceleration of e-government. The second benefit is effectiveness and efficiency of government administration, and third is acceleration of bureaucratic reform will soon be implemented. Then fourth, creation of 
coordination, integration, synchronization, and simplification between government agencies. And fifth, the ease of managing official documents and also easy to use.

The Information System flow of the Electronic Service Manuscript (Nadine) application is below.

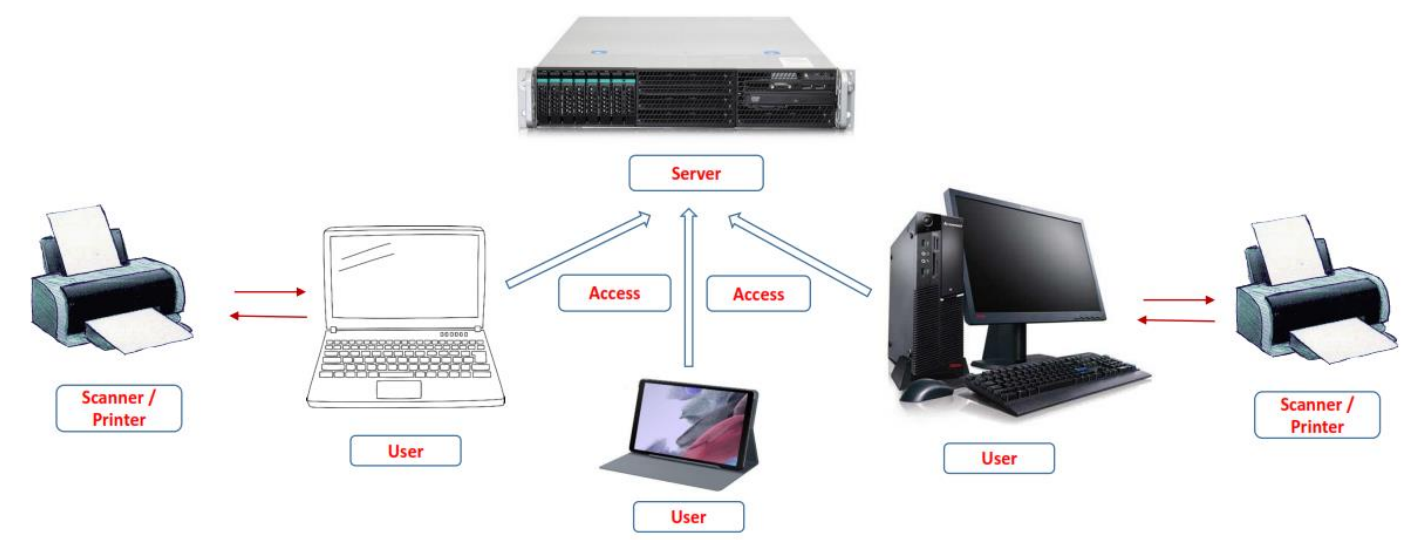

Figure $1:$ Nadine Architectural

An explanation of Nadine's architectural description is as follows:

1. Servers and databases are infrastructure for installing and storing application data.

2. Servers and databases provide applications through computer network infrastructure, both intranet and internet.

3. Users can scan/transfer media (scanning) documents to store documents electronically.

4. It is also possible to printing a document as needed.

5. Any user can use the application through a computer or other communication device.

By using the Nadine, could to reduce paper for corresponding, moreover correspondence will arrive just in time.

\section{E-Faktur}

Tax invoice is a proof of tax levy for the Taxable Entrepreneur (PKP) who submits the Taxable Goods (BKP) and or the delivery of the Taxable Services (JKP). Taxable Entrepreneurs (PKP) are defined as entrepreneurs who submit Taxable Goods (BKP) and or Taxable Services (JKP) which are subject to tax based on Law no. 42 of 2009.

It means that only the Taxable Entrepreneurs are allowed to issue Tax Invoices, not just entrepreneurs. Formerly the tax invoices were printed from a paper, but due to several reasons government then issued an electronic invoice (e-invoice) namely e-faktur. In order to facilitate services to taxpayers, e-faktur signatured by digital signature, furthermore e-faktur could reporting VAT’s Periodic Tax Return.

The initial regulation that underlies the implementation of the e-faktur is Article 4 paragraph 1 of PMK-151/PMK.03/2013, that Tax Invoice as referred to in Article 2 paragraph (1) is in the form of electronic or paper.

Regulation of the Director General of Taxes Number PER-16/PJ/2014 as a rule under PMK151/PMK.03/2013, states that e-faktur is an electronic tax invoice, which is made through an application or electronic system determined and/or provided by the DGT. To make it easier for 
users, the application has also provided a user manual. In Article 1, it is stated that only certain Taxable Entrepreneurs who have been stipulated by Decree of the Director General of Taxes are allowed to issue e-invoices.

In the latest regulation, namely PMK-18/PMK.03/2021 as an implementation of Law no. 11 of 2020 about Job Creation Act, it is emphasized again about e-invoices in Chapter III of 'VAT and Sales Tax on Luxurious Goods' in article 73.

The Directorate General of Taxes has required all Taxable Entrepreneur (PKP) to make tax einvoice as of October 1, 2020. The latest e-invoicing application is e-faktur 3.0 which is a modification of e-Faktur 2.2, the latest version works automatically because Taxable Entrepreneur (PKP) does not need to input data manually like the previous version. It is also hoped that Taxable Entrepreneur (PKP) will be easier to fill out and report the VAT's Periodic

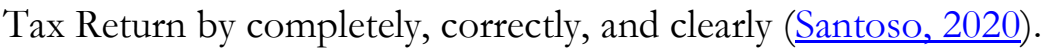

\section{E-Billing and E-Filling}

The efficiency of tax payment needs to be improved with the ease of making a Tax Payment Letter (SSP) so that it can be made more flexible. The process of making SSP is not limited by time and place, taxpayers can make SSP anytime and anywhere, as well as in terms of making tax payments easier. DGT has developed an application that can be used to record SSPs made by taxpayers, then it can be connected directly through tax payment channel..

DGT's e-billing is an electronic system managed by DGT to issue and to manage billing codes which are part of the electronic state revenue system. Billing code is an identification code issued through the DGT billing system for a type of tax payment. E-billing is the implementation of the Second Generation State Revenue Module (MPN G2) system.

DGT's e-filling is an electronic tax reporting submission which is done online and in a real time. Initially, its collaborated with a number of private companies that provided services for online tax reporting, called Application Service Providers (ASP) according to the Director General of Taxes Decree Number: KEP-193/PJ/2015. Lately, taxpayers are given application provided by the DGT to support e-Filing and e-Billing without any costs, namely through sse.pajak.go.id and efiling.pajak.go.id

\section{DJP Online}

The billing code can initially be obtained after the taxpayer fills in sse1.pajak.go.id and sse3.pajak.go.id pages. However, starting January 1, 2020, to get a billing code taxpayer must access the https://djponline.pajak.go.id page.

The DJP's Online https://djponline.pajak.go.id is growing as an online service center for taxpayers. Both to calculate, to make billing, and to report taxes directly. Regulations and general information about the rights and obligations of taxpayers is displayed too. As well as provide any forms related to services required by taxpayers.

More applications are constantly being developed by DGT, especially during the COVID-19 pandemic which is increasingly spreading. The Tax Office (KPP) as part of DGT that is directly related to taxpayers, always innovates in tax services. First, for tax counseling and tax consulting services, the Tax Office (KPP) has established several cellphone numbers that can be contacted, although the call center via office number is still served. Second, the objection submission 
service that previously was a taxpayer directly came to the Integrated Service Center (TPT), nowly made easier by adding features e-objection in the https://djponline.pajak.go.id. And thirdly, submission of other application letters can be submitted in the Tax Office's (KPP) official email.

\section{Taxpayer Satisfaction}

Information system used at DGT Online has been able to provide satisfaction to taxpayers, in process of reporting the Annual Tax Return (SPT Tahunan) with result Very Satisfied. The method used is the PIECES Framework analysis, namely Performance, Information and Data, Control and Security, Efficiency, and Service (Norzhela et al., 2019).

Modernization of Indonesian tax system which is consistently carried out by the Directorate General of Taxes according to perception of taxpayers, has a significant positive on effective tax data processing ( Rusli, 2019).

There was a positive and significant effect on the effectiveness of e-filling. Increasing on compliance of individual taxpayers registered at the Badung Utara Small Tax Office have occured after using e-filling. In addition, security and confidentiality could strengthen of e-filling effectiveness ( $\underline{\text { Adi, 2020)}}$.

The author has conducted a survey on satisfaction of using the electronic tax (e-tax) reporting system to taxpayers registered at Large Taxpayer Office (LTO) Two, in period October 2019 to March 2020, with the number of respondent is 250 taxpayers.

Table 2. Respondent

\begin{tabular}{lc}
\hline & Total \\
\hline $\begin{array}{l}\text { Questionnaires Distributed, } \\
\text { According To Registered Taxpayer } \\
\text { that Must Be Reported Annual Tax }\end{array}$ & 250 \\
Return at LTO Two. & \\
\hline $\begin{array}{l}\text { Numbers of Questionnaires } \\
\text { Retruned All Completed }\end{array}$ & 150 \\
\hline Percentage & $60 \%$ \\
\hline
\end{tabular}

Tabel 3. Respondent's Level of Education

\begin{tabular}{lcc}
\hline & Total & Percentage \\
\hline Associate's Degree & 2 & $1.3 \%$ \\
\hline Bachelor's Degree & 145 & $96.7 \%$ \\
\hline Master Degree & 3 & $2.0 \%$ \\
\hline
\end{tabular}


Review on Digital Transformation Policy of Directorate Generale of Taxes

Riyanto, Clarashinta

There are some indicators of success on information system is efficiency, effectiveness, and satisfaction (Machmud, 2018):

Tabel 4. Indicators of Success on E-Tax Reporting System

\begin{tabular}{|c|c|c|}
\hline & Indicator & \\
\hline \multirow[t]{2}{*}{ 1. Efficiency } & 1. Cost reduction & $\mathrm{X} 1$ \\
\hline & 2. Free of charge & $\mathrm{X} 2$ \\
\hline \multirow[t]{2}{*}{ 2. Effectiveness } & 1. Easy to report & $\mathrm{X} 3$ \\
\hline & 2. Speed up reports & $\mathrm{X} 4$ \\
\hline \multirow[t]{2}{*}{ 3. Satisfaction } & 1. Easy to undertsand & $\mathrm{X} 5$ \\
\hline & 2. Solution for error system & $\mathrm{X} 6$ \\
\hline
\end{tabular}

By using a Likert scale of 1-5, respondents' answers are divided into 5, namely a score of 1 for strongly disagreeing statements, a score of 2 for disagreeing statements, a score of 3 for moderate statements, a score of 4 for agreeing statements, and a score 5 for strongly agreeing statements.

Tabel 5. Validity Test

\begin{tabular}{|l|r|r|r|}
\hline \multicolumn{3}{|c|}{} & \multicolumn{3}{|c|}{ X } \\
\cline { 2 - 4 } & $\begin{array}{c}\text { Pearson } \\
\text { Correlation }\end{array}$ & Sig. (2-tailed) & N \\
\hline X1 & .637 & .000 & 150 \\
\hline X2 & .697 & .000 & 150 \\
\hline X3 & .699 & .000 & 150 \\
\hline X4 & .759 & .000 & 150 \\
\hline X5 & .690 & .000 & 150 \\
\hline X6 & .703 & .000 & 150 \\
\hline X & 1 & & 150 \\
\hline
\end{tabular}

It is known that all questions in the Success of the E-Tax Reporting System, have obtained the calculated $r$ value according to the Pearson Correlation which is between $(0.637-0.759)$, meaning that the calculated $r$ value is greater than $r$ table (0.159), it can be concluded that all research statements are valid.

Tabel 6. Distribution of Respondent's Answer

\begin{tabular}{|c|c|c|c|c|c|c|c|c|c|c|c|}
\hline \multirow[t]{2}{*}{ Item } & \multicolumn{2}{|c|}{ Score 1} & \multicolumn{2}{|c|}{ Score 2} & \multicolumn{2}{|c|}{ Score 3} & \multicolumn{2}{|c|}{ Score 4} & \multicolumn{2}{|c|}{ Score 5} & \multirow[t]{2}{*}{ Average } \\
\hline & $\mathrm{f}$ & $\%$ & $\mathrm{f}$ & $\%$ & $f$ & $\%$ & $f$ & $\%$ & $\mathrm{f}$ & $\%$ & \\
\hline $\mathrm{X} 1$ & 0 & $0.0 \%$ & 15 & $10.0 \%$ & 26 & $17.3 \%$ & 85 & $56.7 \%$ & 24 & $16.0 \%$ & 3.79 \\
\hline $\mathrm{X} 2$ & 0 & $0.0 \%$ & 3 & $2.0 \%$ & 28 & $18.7 \%$ & 19 & $12.7 \%$ & 100 & $66.7 \%$ & 4.44 \\
\hline $\mathrm{X} 3$ & 0 & $0.0 \%$ & 4 & $2.7 \%$ & 26 & $17.3 \%$ & 21 & $14.0 \%$ & 99 & $66.0 \%$ & 4.43 \\
\hline $\mathrm{X} 4$ & 0 & $0.0 \%$ & 4 & $2.7 \%$ & 16 & $10.7 \%$ & 15 & $10.0 \%$ & 115 & $76.7 \%$ & 4.61 \\
\hline X5 & 0 & $0.0 \%$ & 5 & $3.3 \%$ & 19 & $12.7 \%$ & 95 & $63.3 \%$ & 31 & $20.7 \%$ & 4.01 \\
\hline X6 & 0 & $0.0 \%$ & 5 & $3.3 \%$ & 23 & $15.3 \%$ & 96 & $64.0 \%$ & 26 & $17.3 \%$ & 3.95 \\
\hline Average & & & & & & & & & & & \\
\hline
\end{tabular}


Based on the research, it is known that taxpayer satisfaction with the e-tax system in the form of Annual Tax Reporting, obtains an average satisfaction value of 4.2 from a scale of 1 to 5 . It means that taxpayers who are registered in the Large Taxpayer Office (LTO) Two, get satisfaction with the use of an automated reporting system.

\section{Reporting Compliance}

Satisfaction with e-system, can be reflected in increasing of Annual Tax Return (SPT Tahunan) reporting over last three years, for all taxpayers registered on the DGT.

Table 7. Annual Tax Return Reporting For Last 3 Year

\begin{tabular}{ccc}
\hline Year & $\begin{array}{c}\text { Quantity of Annual Tax Return } \\
\text { (in Million) }\end{array}$ & $\begin{array}{c}\text { Percentage of Registered } \\
\text { Annual Tax Return Required } \\
\text { To Report (\%) }\end{array}$ \\
\hline 2018 & 12.55 & 71 \\
\hline 2019 & 13.37 & 73 \\
\hline 2020 & 14.75 & 78 \\
\hline
\end{tabular}

Electronic reporting of Annual Tax Return (SPT Tahunan) is the best solutions in tax reporting, especially during the Covid-19 pandemic, where there are restrictions on direct reporting at Tax Office (KPP). The Director of Extension, Services and Public Relations (P2Humas) of the Directorate General of Taxes (DGT) said that there was an increase in electronic reporting both through e-filing, e-form, and e-SPT facilities by $26.1 \%$, it means that there has been increase approximately 2.2 million Annual Tax Return (SPT Tahunan) in 2020 submissions, compared to 2019 (Santoso, 2020).

\section{Digital Transformation and EoDB}

The use of digital applications in addition to facilitating services for taxpayers, could support the ease of doing business in a country too. In the Ease of Doing Business (EODB) published by the World Bank, easy of paying taxes as one of the assessment indicators. EODB is an index of a country, which is compiled in a certain rank and score for all countries assessed. Although EODB is not a guide for investing, it can be used as a reference to improve a country in order to attract foreign investment.

The use of technology to shorten bureaucratic will encourage time and cost efficiency. The ease of paying taxes and tax reporting, that leveraging digital transformation of DGT, has resulted in a good EODB score. It's increased by 7.4 points from 68.4 in the 2019 EODB evaluation, to 75.8 in the 2020 EODB evaluation. Overall, Indonesia has still at rank 73 out of 190 countries assessed for the 2019 and 2020 fiscal years. The World Bank concludes that ease of paying taxes in Indonesia is getting easier, in line with development of online tax reporting and payment system. (Wildan, 2021). 


\section{CONCLUSION}

Digital transformation is a sustainable process required by stakeholders. The key to the success of digital transformation not only in technology, but also in concept of digital culture implemented by HR in the field of Information and Communication Technology. There needs to be a mature blueprint, supportive regulations, and commitment from the leadership. With all of these things, digital transformation will be able to provide a good improvements to public services.

The use of digital applications in providing services optimally to taxpayers, has resulted in increasing the compliance of Annual Tax Return (SPT Tahunan). Digital transformation carried out by the Directorate General of Taxes, has received recognition from the World Bank in terms of increasing the ease of payment and tax reporting, at the Ease of Doing Business (EODB) Indonesia assessment in 2020.

\section{REFERENCE}

Adi, I. K. Y. (2020). Efektifitas E-Filing Terhadap Peningkatan Kepatuhan Wajib Pajak Orang Pribadi dengan Tingkat Keamanan dan Kerahasiaan Sebagai Variabel Moderasi (Studi Empiris Pada Kantor Pelayanan Pajak Pratama Badung Utara). Journal of Applied Management and Accounting Science, 2(1), 53-66. https://doi.org/10.51713/jamas.v2i1.26

Amir, H., Asafu-Adjaye, J., \& Ducpham, T. (2013). The impact of the Indonesian income tax reform: A CGE analysis. Economic Modelling, 31, 492-501. https://doi.org/10.1016/j.econmod.2012.12.018

Cahyadini, A., Dewi, S., Sugiharti, D. K., \& Muttaqin, Z. (2021). Direct Tax for Digital Platform During the COVID-19 Pandemic: Study in Indonesia. Journal of Southwest Jiaotong University, 56(2), 271-280. https://doi.org/10.35741/issn.0258-2724.56.2.22

Ebert, C., \& Duarte, C. H. C. (2018). Digital Transformation. IEEE Software, 35(4), 16-21. https://doi.org/10.1109/MS.2018.2801537

Guo, Y. M., \& Shi, Y. R. (2021). Impact of the VAT reduction policy on local fiscal pressure in China in light of the COVID-19 pandemic: A measurement based on a computable general equilibrium model. Economic Analysis and Policy, 69, 253-264. https://doi.org/10.1016/j.eap.2020.12.010

Hadiono, K., \& Santi, R. C. N. (2020). Menyongsong Transformasi Digital Conference: Optimalisasi Potensi Masyarakat di Era Society 5.0 untuk Mewujudkan Indonesia Maju dan Berkarakter. In K. Hadiono (Ed.), Menyongsong Transformasi Digital (pp. 81-84). Universitas Stikubank.

https://www.researchgate.net/publication/343135526_MENYONGSONG_TRANSFOR MASI_DIGITAL

Hajawiyah, A., Suryarini, T., Kiswanto, \& Tarmudji, T. (2021). Analysis of a tax amnesty's effectiveness in Indonesia. Journal of International Accounting, Auditing and Taxation, 44, 100415. https://doi.org/10.1016/j.intaccaudtax.2021.100415

Machmud, R. (2018). Kepuasan Penggunaan Sistem Informasi (R. Machmud (ed.); I). Ideas Publishing. https://repository.ung.ac.id/karyailmiah/show/2450/rizan-machmud-buku-kepuasanpenggunaan-sistem-informasi.html

Mergel, I., Edelmann, N., \& Haug, N. (2019). Defining digital transformation: Results from expert interviews. Government Information Quarterly, 36(4), 101385. https://doi.org/10.1016/j.giq.2019.06.002 
Norzhela, B., Rauf, S. A., \& Hermawansyah, A. (2019). Analisis Efektivitas Kepuasan Wajib Pajak Dalam Pengisian Laporan SPT DJP Online. J-Sim : Jurnal Sistem Informasi, 2(2), 55-59. http://ojs.stmik-borneo.ac.id/index.php/J-SIm/article/view/50

Prastiwi, W., \& Frecilia, Y. (2014). Literature review. Widuri Raharja. https://widuri.raharja.info/index.php?title=Literature_review

Rahwani, N. R., Sadewa, M. M., Qalbiah, N., Mukhlisah, N., Artha W, P., \& Nikmah, N. (2019). XBRL based Corporate Tax Filing in Indonesia. Procedia Computer Science, 161, 133-141. https://doi.org/10.1016/j.procs.2019.11.108

Rusli, Y. M. (2019). Pengaruh Efektivitas Penerapan E-filling dan Modernisasi Sistem Perpajakan Indonesia Terhadap Efektivitas Pemrosesan Data Perpajakan. Jurnal Akuntansi Bisnis, 12(1). https://doi.org/10.30813/jab.v12i1.1509

Santoso, Y. I. (2020, September 30). Mulai 1 Oktober, Pengusaha Kena Pajak Wajib Buat Faktur Pajak Elektronik. Tabloid Kontan, 11. https://nasional.kontan.co.id/news/mulai-1-oktoberpengusaha-kena-pajak-wajib-buat-faktur-pajak-elektronik

Sreeramula, S., \& Rahardjo, D. (2021). Estimating COVID-19 Rt in Real-time: An Indonesia health policy perspective. Machine Learning with Applications, 6, 100136. https://doi.org/10.1016/j.mlwa.2021.100136

Susanti, N., \& Widajatun, V. W. (2021). MSMEs Understanding of Taxation During the COVID-19 Pandemic. Journal of Innovation and Community Engagement, 2(1), 35-46. https://doi.org/10.28932/jice.v2i1.3689

Tibulca, I.-L. (2021). The impact of the COVID-19 pandemic on tax revenues in the EU. Economic Research-Ekonomska Istraživanja, 1-18. https://doi.org/10.1080/1331677X.2021.1954967

Tosepu, R., Gunawan, J., Effendy, D. S., Ahmad, L. O. A. I., Lestari, H., Bahar, H., \& Asfian, P. (2020). Correlation between weather and Covid-19 pandemic in Jakarta, Indonesia. Science of The Total Environment, 725, 138436. https://doi.org/10.1016/j.scitotenv.2020.138436

Wildan, M. (2021, September). Ada Temuan, Lima Edisi Terakhir Laporan EoDB World Bank Dievaluasi. DDTC. DDTC News, 1. https://news.ddtc.co.id/ada-temuan-lima-edisiterakhir-laporan-eodb-world-bank-dievaluasi-23553?page_y $=1390$

Windarwati, H. D., Oktaviana, W., Mukarromah, I., Ati, N. A. L., Rizzal, A. F., \& Sulaksono, A. D. (2020). In the middle of the COVID-19 outbreak: Early practical guidelines for psychosocial aspects of COVID-19 in East Java, Indonesia. Psychiatry Research, 293, 113395. https://doi.org/10.1016/j.psychres.2020.113395 